\title{
SPROUTING AND REGENERATION OF SENSORY AXONS AFTER DESTRUCTION OF ENSHEATHING GLIAL CELLS IN THE LEECH CENTRAL NERVOUS SYSTEM ${ }^{1}$
}

\author{
ELLEN J. ELLIOTT' ${ }^{2}$ AND KENNETH J. MULLER ${ }^{3}$
}

Department of Embryology, Carnegie Institution of Washington, Baltimore, Maryland 21210

Received February 1, 1983; Revised April 15, 1983; Accepted April 28, 1983

\begin{abstract}
To test the importance of glia during regeneration of mechanosensory neuron axons in the leech central nervous system, individual glial cells that ensheathed the axons were destroyed by intracellular protease injection. Recordings with intracellular microelectrodes showed that glial-desheathed axons re-established synaptic connections with their appropriate target cell, a motor neuron, as frequently and as selectively as control, glial-ensheathed axons. Intracellular staining with horseradish peroxidase showed that desheathed regenerating axons sprouted more than controls, and loss of the glial cell in some cases caused uninjured (intact) axons to sprout. Successful, accurate regeneration could occur whether axons grew along normal or along aberrant pathways. The distal stumps of some sensory axons severed from cell bodies and maintained in organ culture survived without their glial sheath for up to 3 weeks. These experiments show that, although loss of the glial cell affects sensory axon growth, the glial cell is not required for accurate axonal regeneration in the leech central nervous system.
\end{abstract}

The extent to which axons regenerate may depend upon the axonal environment (Kao et al., 1977; Stensaas et al., 1979; Weinberg and Raine, 1980; Aguayo et al., 1982), of which glial cells are a major part. Glia have been suggested in some cases to guide regenerating axons (Ramon y Cajal, 1928; Reier and Webster, 1974; Turner and Singer, 1974; Murray, 1976) and in others to obstruct growth (Clemente, 1964; Stensaas, 1979; Aguayo et al., 1982). The central nervous system (CNS) of the leech, in which axons regenerate accurately (Baylor and $\mathrm{Ni}$ cholls, 1971; Jansen and Nicholls, 1972; Frank et al., 1975; Wallace et al., 1977; Muller and Carbonetto, 1979), offers an unusual opportunity to examine the role of glia in axonal regeneration by selectively ablating glial cells and then studying the regeneration of axons without their glial sheath.

The neuronal cell bodies in the leech CNS lie in a

\footnotetext{
${ }^{1}$ We thank Ms. B. Thomas for excellent technical assistance, Drs. R. Rohwer and $\Lambda$. Mason for eriticisms of the manuscript, and Ms. S. Satchell for typing and editing. This work was supported in part by postdoctoral fellowships from the Carregie Corporation and the $\mathrm{Na}$ tional Multiple Sclerosis Society to E. J. E. and by a McKnight Foundation Neuroscience Development Award and National Institutes of Health Grant NS-15014.

${ }^{2}$ Present address: Department of Zoology, University of Maryland, College Park, MD 20742.

${ }^{3}$ Present address: Department of Physiology and Biophysics, University of Miami School of Medicine, Miami, FL 33101.
}

series of segmental ganglia, and the axons lie in three connectives, two lateral and one medial, joining the ganglia. In each lateral connective, a single glial cell ensheaths all the axons (about 3000) and extends the entire distance from one ganglion to the next (up to 5 $\mathrm{mm}$ ). The large glial cells can be impaled with micropipettes (Kuffler and Potter, 1964) and thus can be killed by intracellular injection of protease, a technique of cell ablation that leaves surrounding cells intact (Parnas and Bowling, 1977). In the experiments described below, individual connective glial cells were killed by intracellular protease injection, and the regeneration of severed mechanosensory axons in the absence of their normal glial sheath was then followed by physiological and morphological means. We have found that elimination of the glial cell does affect the growth of these axons; nevertheless, the desheathed axons are able to regenerate with normal frequency and accuracy. Some of these findings have been reported previously in preliminary form (Elliott and Muller, 1982).

\section{Materials and Methods}

Surgical procedures. Leeches (Hirudo medicinalis) were obtained from Ricarimpex (Audenge, France) and from Blutegelimport und Versand (Rechlinghausen-Sud, West Germany). In leeches anesthetized with $15 \mathrm{~mm}$ chlorobutanol, the nerve cord was exposed and individual lateral connective glial cells were impaled with bevelled 
microelectrodes containing protease (subtilopeptidase A; Sigma, type VIII; $0.6 \%$ in solution with $0.2 \mathrm{M} \mathrm{KCl}$ and $0.2 \%$ Fast Green FCF) (Parnas and Bowling, 1977; Bowling et al., 1978; Scott and Muller, 1980). Glial cells were identified by their large resting potentials (up to -80 $\mathrm{mV}$ ) and the absence of action potentials. Sufficient protease was injected by pressure to give a lasting green color in the region of the injection.

Leeches were placed in leech Ringer's solution (115 $\mathrm{mM} \mathrm{NaCl}, 4 \mathrm{mM} \mathrm{KCl}, 1.8 \mathrm{mM} \mathrm{CaCl}_{2}, 10 \mathrm{~mm}$ Tris maleate, $\mathrm{pH}$ 7.4) for 2 days after the operation and then transferred to spring water. For regeneration studies, axons were later severed by crushing the connectives with a pair of fine forceps in leeches anesthetized in $8 \%$ ethanol. In experiments in which axons were severed by cutting the connectives with two staggered cuts, one on each side and each transecting slightly more than half the nerve cord, regeneration occurred in only one preparation. Thus, these experiments were not included in the results discussed below.

Physiology. The neurons chosen for study were the lateral and medial pressure (P) and the lateral nociceptive $(\mathrm{N})$ mechanosensory neurons. Every segmental ganglion in the leech contains two each of these sensory neurons, arranged bilaterally symmetrically. Each sensory neuron sends an axon anteriorly and another posteriorly through the ipsilateral connectives to synapse in the adjacent ganglia with the ipsilateral $\mathrm{L}$ motor neuron (Jansen and Nicholls, 1972; Jansen et al., 1974) which excites the longitudinal muscles (Stuart, 1970). The medial $\mathrm{N}$ cell was not studied in most of these experiments because, in control experiments, synaptic connections between this cell and the L cells of the adjacent ganglia were weak or undetectable.

The selected sensory neurons were tested for synaptic connections with the $\mathrm{L}$ motor neuron by intracellular stimulation of a sensory cell while recording from the ipsilateral L motor neuron in the next ganglion. For these experiments, the preparation was bathed in leech Ringer's solution of higher than normal $\mathrm{Ca}^{2+}(7.5 \mathrm{mM}$ $\mathrm{CaCl}_{2}$ substituted for $\mathrm{NaCl}$ ) in order to increase the amplitude of synaptic potentials. To test whether synaptic potentials were monosynaptic, preparations were bathed in leech Ringer's having elevated $\mathrm{Ca}^{2+}(15 \mathrm{nM})$ and $\mathrm{Mg}^{2+}(18 \mathrm{mM})$ concentrations, with isomolar substitution of $\mathrm{CaCl}_{2}$ and $\mathrm{MgCl}_{2}$ for $\mathrm{NaCl}$ (Nicholls and Purves, 1970). Elevated $\mathrm{Mg}^{2+}$ blocks most chemical synapses in the leech, but elevated $\mathrm{Ca}^{2+}$ restores synaptic transmission. Both divalent cations lower excitability, however, and polysynaptic pathways involving an excitable interneuron remain blocked. Unexpectedly, treatment with high $\mathrm{Ca}^{2+}$-high $\mathrm{Mg}^{2+}$ Ringer's solution was often detrimental to the ultrastructure of regenerating preparations, making it impossible to determine which connective glial cell had been killed; thus, this treatment was not routinely applied.

Histology. After electrophysiological records were taken, sensory cells were injected with horseradish peroxidase (HRP; Sigma, type VI; $2 \%$ in $0.2 \mathrm{M} \mathrm{KCl}$ with $0.2 \%$ Fast Green FCF). If one cell had regenerated successfully, it and its contralateral homologue were injected. If more than one cell on a side had regenerated, then only one of these was injected. If no sensory cells had established synaptic connections with the L cell, then paired cells were chosen randomly for injection. After HRP injection, the preparation was placed in modified Leibowitz-15 culture medium containing gentamicin and mycostatin (Fuchs et al., 1981) for 2 to 3 days to allow diffusion of the HRP throughout the axonal processes. The tissue was then fixed in $1.6 \%$ glutaraldehyde and $0.8 \%$ paraformaldehyde in $0.08 \mathrm{M}$ sodium cacodylate, pH 7.4, containing $5 \mathrm{~mm} \mathrm{CaCl}_{2}$. Reaction with a saturated solution of $3,3^{\prime}$-diaminobenzidine (Aldrich, technical grade, filtered before use) and $\mathrm{H}_{2} \mathrm{O}_{2}$ was followed visually (Muller and McMahan, 1976).

In early experiments, morphological analysis was performed on uncleared preparations at this point. The tissue was then postfixed in $1 \% \mathrm{OsO}_{4}$ in $0.1 \mathrm{M}$ sodium

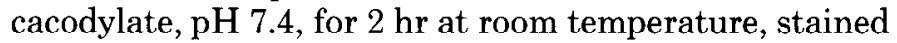
en bloc with ice-cold maleate-buffered uranyl acetate, $\mathrm{pH}$ 5.2 , dehydrated in graded ethanols, and embedded in Epon 812. Thin sections were stained on the grid with lead citrate and examined in a JEOL JEM-100S electron microscope. In examination of such uncleared preparations in the whole mount, thin processes of sensory axons were often not visible. For this reason, in later experiments the tissue was not treated with $\mathrm{OsO}_{4}$ but with hafnium tetrachloride, $\mathrm{HfCl}_{4}$, which provided contrast for electron microscopy but did not darken the tissue (Stewart, 1981) and thus allowed examination of the cleared whole mount embedded in Epon. Most of the morphological analysis reported below, such as determination of pathways of growth or sprouting patterns, was done on preparations treated with $\mathrm{HfCl}_{4}$.

In some preparations extracellular carbohydrate-containing material was stained with ruthenium red (Luft, 1971a, b) and the tissue then was prepared for electron microscopy. Ruthenium red did not readily penetrate the connective tissue capsule surrounding the leech nerve cord. Therefore, sections for electron microscopy were taken near the cut ends of the nerve cord, where the stain was able to penetrate to the extracellular space between axons and the glial sheath.

\section{Results}

Destruction of glial cells. Protease-injected glial cells that appeared light green upon injection and for some minutes afterward were destroyed within 1 week (Elliott and Muller, 1982), as determined by light microscopy of $2-\mu \mathrm{m}$ thick sections through the connectives (Fig. $2 C$ ) and electron microscopy of thin sections (Fig. 1). Most axons in the lateral connectives appeared morphologically normal for up to 10 months (the longest time observed) after destruction of their ensheathing glial cell (Fig. 1). Initially, the space that the injected cell had occupied became filled with cellular debris and with numerous small phagocytotic cells. Such small cells, often containing bundles of intermediate filaments resembling those in the large glial cell, were also present several weeks later when the extracellular debris had disappeared. In ensuing weeks, these "microglia" ensheathed short lengths of axons (Fig. 1B).

In an attempt to detect glial-associated extracellular material left behind after the glial cell had been killed, a 

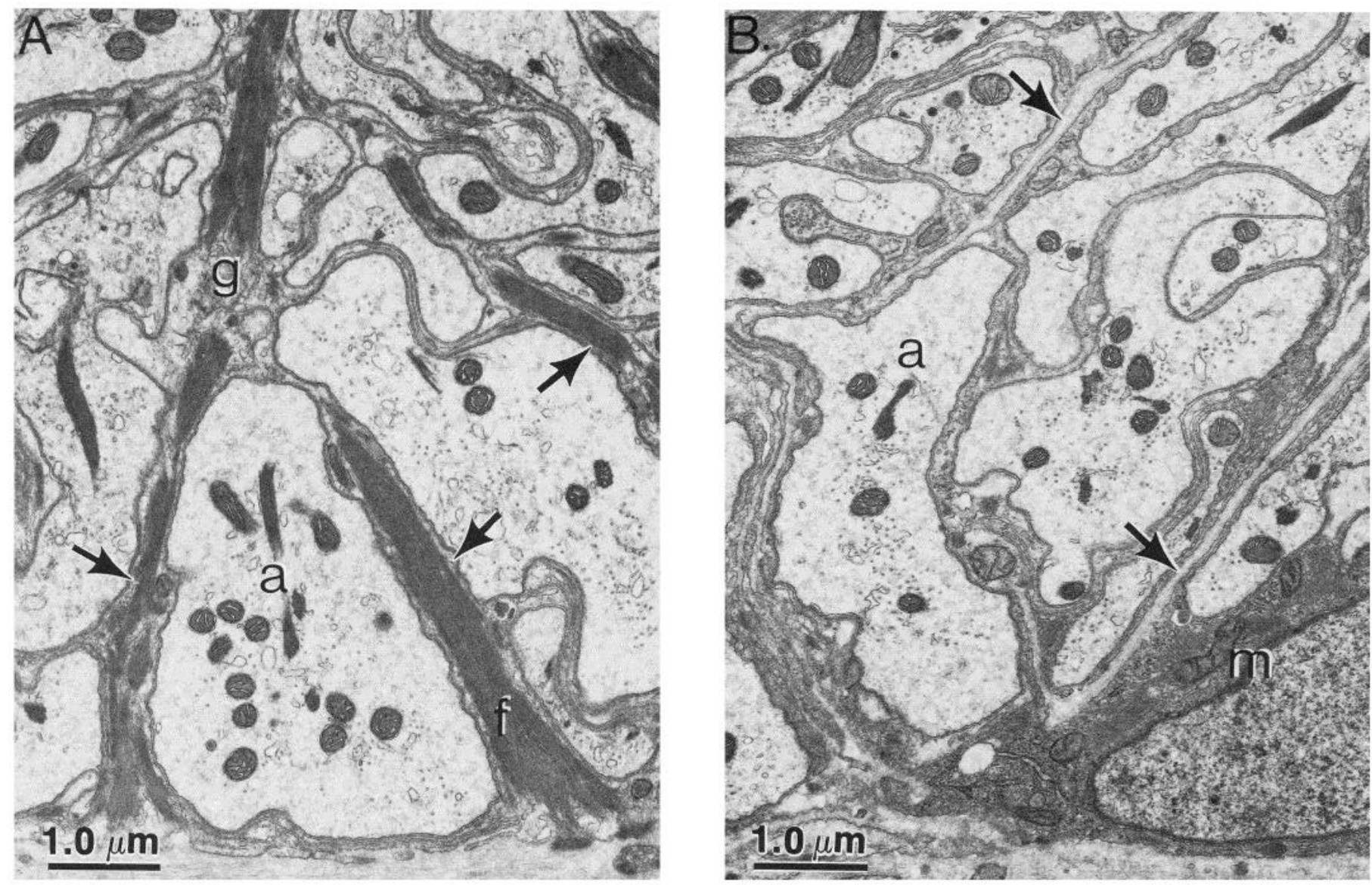

Figure 1. Electron micrograph of a cross-section through a leech nerve cord in which one of the two connective glial cells was injected with protease 2 months earlier. $A$, In the uninjected control connective the glial cell $(g)$ remains intact and displays a normal morphology; i.e., it contains bundles of intermediate filaments $(f)$ and a branching network of processes $($ arrows ) that ensheath the axons $(a)$ of the connective. $B$, In the other lateral connective, the protease-injected glial cell has disappeared and the branching glial processes have been replaced by channels of extracellular space (arrows). Axons (a) remain normal and are ensheathed to some extent by a microglial cell $(\mathrm{m})$. Tissue was stained en bloc with osmium and uranium and sections were stained with lead.

ruthenium red stain was used. Ruthenium red stains the extracellular polysaccharide-containing matrix that outlines most cells (Luft, 1971b). In the case of peripheral glial and muscle cells, a specialized, multilayered component of extracellular matrix, the basal lamina, may signal regenerating peripheral axons to reinnervate their original synaptic sites (Sanes et al., 1978). Although there is no basal lamina associated with the glia in the leech CNS, ruthenium red did stain the extracellular material surrounding glial cells and axons. After protease injection and disappearance of the glial cell, no ruthenium red-staining material other than the glycocalyx of the axons remained.

Effect on normal axons of killing the ensheathing glial cell. $\mathrm{P}$ and $\mathrm{N}$ sensory axons whose ensheathing glial cell had been killed continued to conduct impulses and evoke excitatory synaptic potentials in the ipsilateral $\mathrm{L}$ motor neuron of the next ganglion for up to 10 months. Normal action potentials were recorded from the sensory cell bodies, which retained their glial sheath. The shape of the action potential of the axons lacking their glial sheath was not determined. In experiments by others (Baylor and Nicholls, 1969; Ready and Nicholls, 1979; Fuchs et al., 1981, 1982) mechanical removal of the glial cell from sensory neuron cell bodies did not measurably alter single impulses recorded in them. After a 2- to 3-day recovery from the operation, leeches in which a connective glial cell had been killed behaved, i.e., swam and fed, normally.

Injection of HRP into sensory neurons in some of the above preparations showed that in half the cases ( 8 of 19) the desheathed axons had sprouted (Fig. 2). Sprouting of uninjured, desheathed axons was seen from 3 weeks (the earliest time investigated) to 10 months (the longest time investigated) after protease injection. For those neurons whose desheathed axons had sprouted, their other axons, that extended from the opposite side of the ganglion and thus remained ensheathed by a glial cell, did not sprout. An attempt was made to determine whether the observed axonal sprouting might result from injury to axons by microelectrode penetration or by protease released from the disintegrated glial cell. Glial cells were impaled with protease-filled electrodes but not injected and the electrode was then withdrawn. With the injection electrode positioned just outside the glial cell membrane, protease was injected into the extracellular space beneath the capsule of connective tissue that sur- 
rounds the axons and glial cell. In 20 such experiments, only once was any sprouting of sensory axons seen, and in that case the sprouts were not extensive. (To confirm that the above procedure did fill the extracellular space surrounding the axons with protease, a still larger molecule, HRP, was injected extracellularly in the same way. The sectioned tissue showed intense HRP staining in the extracellular space.)

Degree of sensory axon regeneration in the absence of glia. $\mathrm{P}$ and $\mathrm{N}$ sensory neurons normally make monosynaptic, excitatory connections with the $\mathrm{L}$ motor neurons of the same ganglion and with $\mathrm{L}$ motor neurons in the adjacent anterior and posterior ganglia (Nicholls and Purves, 1970; Jansen and Nicholls, 1972; Jansen et al., 1974). If the sensory neuron axons are severed in the connectives, they can regenerate and re-establish monosynaptic, excitatory connections with the L motor neuron of the adjacent ganglion (Jansen and Nicholls, 1972). Regeneration to the anterior ganglion is often accompanied by a polysynaptic, inhibitory connection that masks the excitatory connection to the $\mathrm{L}$ motor neuron ("Baylor's Law," Jansen et al., 1974). Therefore, in most of the present experiments, regeneration to the posterior ganglion was studied, and all statistics reported are for this type of experiment.

In the absence of the ensheathing glial cell, severed $\mathrm{P}$ and $\mathrm{N}$ sensory axons were able to regenerate and establish excitatory synaptic connections with the $\mathrm{L}$ motor neuron about as frequently as did normal, glial-ensheathed axons. Of a total of 162 desheathed sensory axons tested at times longer than 2 weeks, 24 (or 15\%) were found by physiolgical testing to have reconnected with their proper target, the L motor neuron, compared to 31 of 173 (or $18 \%$ ) axons tested on control sides (Table I). Half of the regenerated axons were of medial $\mathrm{P}$ cells ( 28 of 55), a third were of lateral $P$ cells (19 of 55), and a sixth were of lateral $\mathrm{N}$ cells (8 of 55 ). In the few preparations tested, regenerated synaptic potentials persisted in high $\mathrm{Ca}^{2+}$-high $\mathrm{Mg}^{2+}$ Ringer's solution (Nicholls and Purves, 1970), indicating that they were monosynaptic.

In almost half ( 13 of 32 ) of the preparations in which some successful regeneration was found, more than one sensory cell had regenerated an axon, sometimes exclusively on either one side or the other (4 of 32 ), but more often on both the control and the protease-injected sides (9 of 32). These preparations accounted for more than half ( 36 of 55) of the axons that had regenerated successfully. Analysis using the binomial distribution showed that the observed distribution of regenerated axons is consistent with each axon's regeneration being an independent event. Whether or not this was the case, the presence or absence of the ensheathing glial cell did not affect the probability of regeneration.

Selectivity of sensory axon regeneration in the absence of glia. Experiments by others (Jansen and Nicholls, 1972; Wallace et al., 1977) have indicated that regenerating sensory axons do occasionally establish synaptic connections with cells other than the $\mathrm{L}$ motor neuron. We investigated the selectivity of regeneration in the absence of the ensheathing glial cell by looking for such connections with other cells in normal preparations as well as in regenerated preparations with and without glia. The target cells tested for synaptic connections with sensory cells were identified by position only and were located in two regions on the dorsal surface of the ganglion. One region was that normally occupied by cells 1 to 8 , a group of motor neurons that, like the $\mathrm{L}$ cell, innervate longitudinal muscles (Stuart, 1970; Ort et al., 1974). The second region was that immediately surrounding the $\mathrm{L}$ motor neuron.

In control experiments, 9 of $10 \mathrm{P}$ cells examined evoked small EPSPs in adjacent ganglia on a cell from one or both of the groups described above (Fig. 3A). Synaptic potentials in cells near the $L$ motor neuron were generally larger than those for cells in the region of the other motor neurons and appeared to be monosynaptic by the criterion of persistence in high $\mathrm{Ca}^{2+}$-high $\mathrm{Mg}^{2+}$ Ringer's solution. The smaller synaptic potentials of cells in the latter group were not tested with high $\mathrm{Ca}^{2+}$-high $\mathrm{Mg}^{2+}$ solution.

In the case of sensory $\mathrm{P}$ axons that had regenerated to the $\mathrm{L}$ cell (and were not candidates for fusion), 4 of 5 tested also made weak excitatory synaptic connections with cells from one or both of the above groups. Two of these four axons lacked their glial sheath and two were normally glial ensheathed. In one case, a regenerated, glial-ensheathed axon made synaptic connections, one of them inhibitory, with four other cells (Fig. $3 B$ ). This may represent a decrease in selectivity of connections compared to normal, uninjured preparations, since inhibitory synapses and connections with more than two cells other than the L cell were not seen in normal preparations. In the case of $\mathrm{P}$ sensory axons that had not regenerated to the $\mathrm{L}$ cell, 3 of 15 tested had formed excitatory synapses with one of the other cells tested. One of these regenerated axons lacked its glial sheath and the other two were normally glial ensheathed. These results indicate that sensory axons lacking a glial sheath regenerate as selectively as do axons with a normal glial sheath.

Regeneration along normal pathways; possible axon fusion. In addition to regeneration by new growth for the entire distance from lesion to target, mechanosensory axons may infrequently regenerate by a process of rejoining, or fusion, of the proximal axon stump with the distal stump (Macagno et al., 1982; DeRiemer et al., 1983), as has been suggested in other invertebrate systems (Hoy et al., 1967; Hoy, 1969). An attempt was made to determine whether loss of the glial cell might affect this process by examining a number of preparations too soon ( 1 to 2 weeks) after injury for regeneration by regrowth to the target to have occurred. Of a total of 67 control and 68 desheathed axons examined, none had fused with their distal stumps.

In experiments completed at times longer than 2 weeks after injury, it was not possible to distinguish those axons that might have regenerated by fusion from those that regenerated by regrowth along normal pathways, since sufficient time had elapsed to allow regrowth of severed axons to the target and since sensory axons can regenerate by new growth along pathways indistinguishable from normal (Macagno et al., 1982). Of the 55 regenerated axons that were found by physiological testing to 

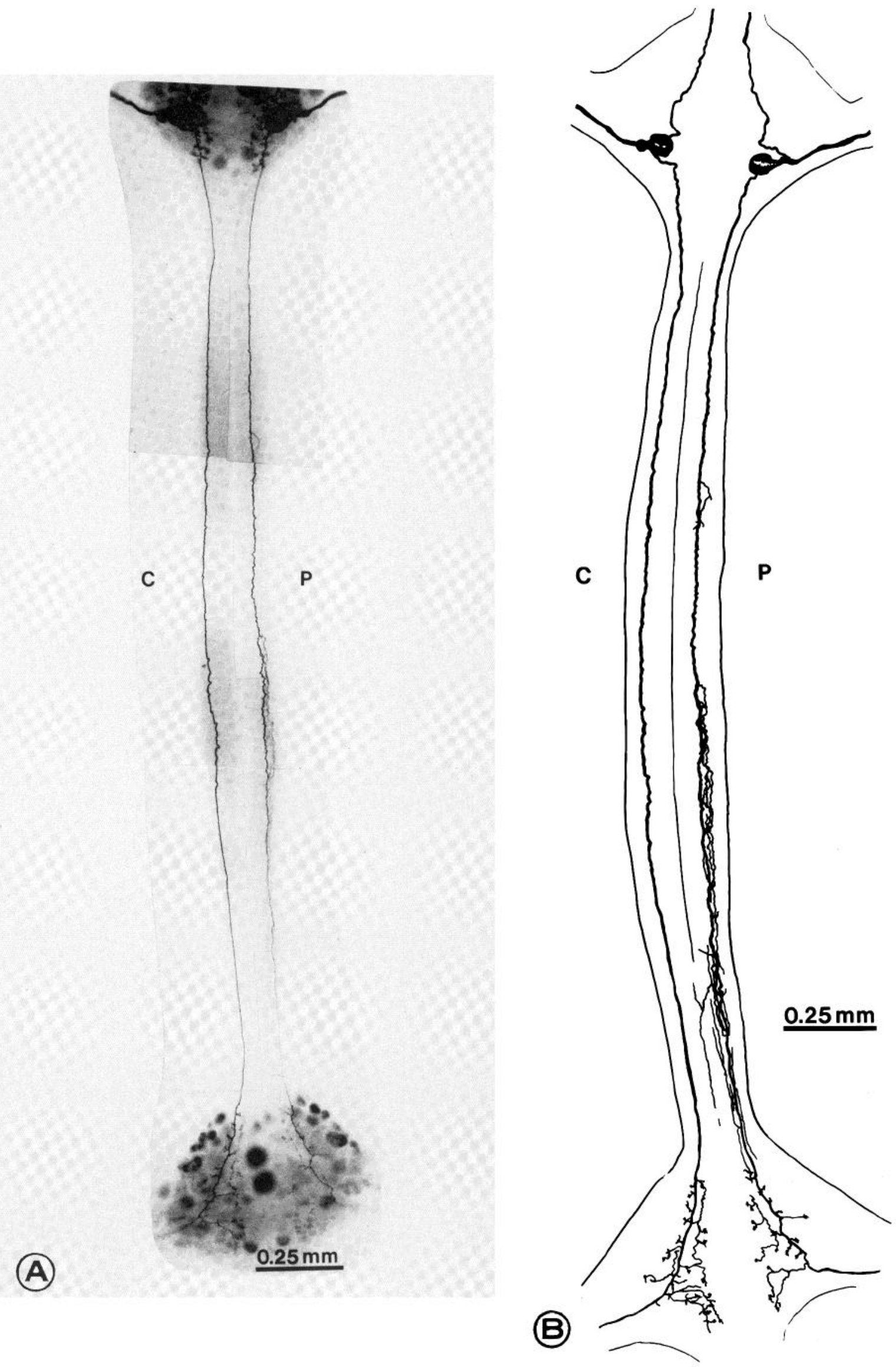

Figure 2, $A$ and $B$ 


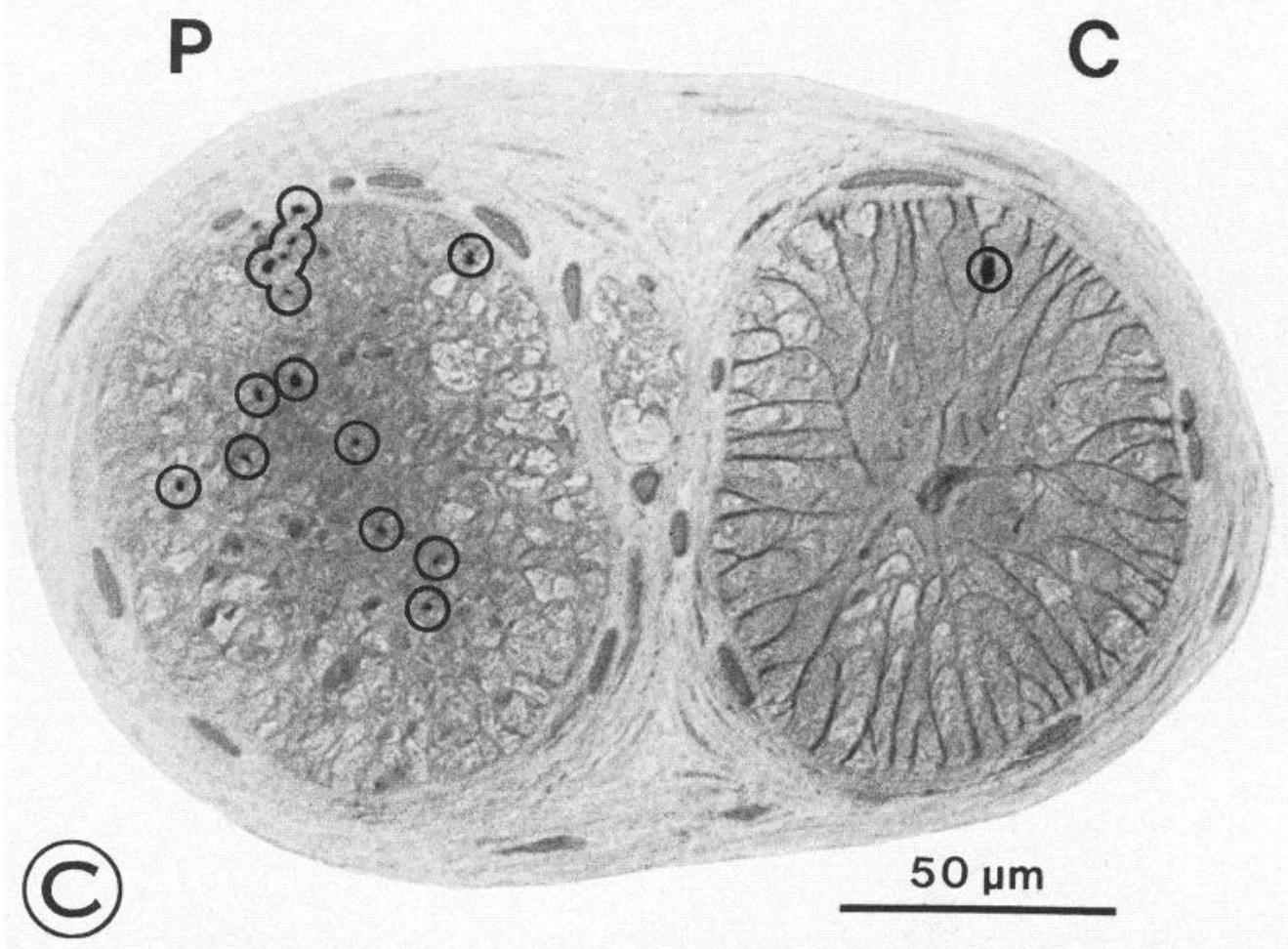

Figure 2. Sprouting by an intact, desheathed axon. A, Photomicrographic montage of two ganglia and the nerve cord joining them, in which one of the connective glial cells was killed by protease injection $10^{1 / 2}$ months earlier, and the medial pressure cell on each side of the anterior ganglion was injected with HRP. The axon on the protease-injected side $(P)$ has sprouted, whereas the axon on the control side $(C)$ has not. $B$, A camera lucida drawing of the same preparation shows the fine sprouts more clearly. Dendritic processes in the anterior ganglion have not been drawn. The preparation was treated with hafnium and mounted whole in Epon (see the text). $C$, Light micrograph of a $2-\mu \mathrm{m}$-thick cross-section through the connectives of a preparation similar to the one shown in $A$ and $B$, showing the distribution of $\mathrm{P}$ cell sprouts on the protease-injected side. Thin sections of this same preparation are shown in Figure 1. Ventral is at the top.

synapse with their L cell targets, 40 were injected with HRP. Eleven of these HRP-injected regenerated axons were candidates for fusion, for in these cases axon caliber, position in the connective, and branching pattern in the target ganglion all looked normal. Eight of these normalappearing axons were on control sides, and three were on sides with the glial cell killed (Table I). This difference is not statistically significant.

Regeneration along abnormal pathways. Twelve of the HRP-injected, regenerated axons had regrown along abnormal pathways, as judged by location within the connectives. Nine of these, three desheathed axons and six control axons, had grown the entire distance from crush to target cell. The remaining three axons, all desheathed, did not extend HRP-filled processes all the way to the target ganglion (Fig. $4 D$ ) even though physiological experiments had shown that they had re-established synaptic connections with their target $\mathrm{L}$ cells. Insufficient filling of the fine regenerated processes seems an unlikely explanation for these cases, since HRP fully filled the same cells' uninjured axons, including the fine processes in the next anterior ganglion, and since the density of the stain was uniform along the processes. Another possibility is that the axons either synapsed on other cells in the ganglion containing the sensory cell body or synapsed in the connectives on processes, perhaps distal axon stumps, that then synapsed on the L cell. Sensory axons regenerating in the presence of their normal glial sheath have been observed to form synapses with other axons in the connective after a lesion (Fernandez and Fernandez, 1974; Muller, 1979) and leech neurons can form synapses on their severed stumps (Carbonetto and Muller, 1977). Although the synaptic potentials in the L cell in these three preparations followed sensory axon impulses one for one and with a fixed latency, they were not tested with high $\mathrm{Ca}^{2+}$-high $\mathrm{Mg}^{2+}$ Ringer's solutions. Thus, it cannot be concluded from the physiology whether these regenerated connections were monosynaptic or polysynaptic.

How many of the remaining 32 regenerated axons ( 15 desheathed axons and 17 on control sides) had grown along aberrant pathways and how many along normal pathways could not be determined, either because the preparation had been treated with $\mathrm{OsO}_{4}$, or because the HRP had not sufficiently filled the ends of the axons, or because the cells had not been injected with HRP. From those cells that were studied both morphologically and physiologically, it is clear that the ensheathing glial cell is not required for axon growth that results in accurate regeneration.

Time course of regeneration. Table I summarizes experiments performed from 2 weeks after injury, the earliest time that successful regeneration was seen, to 20 weeks. The frequency of regeneration increased with 


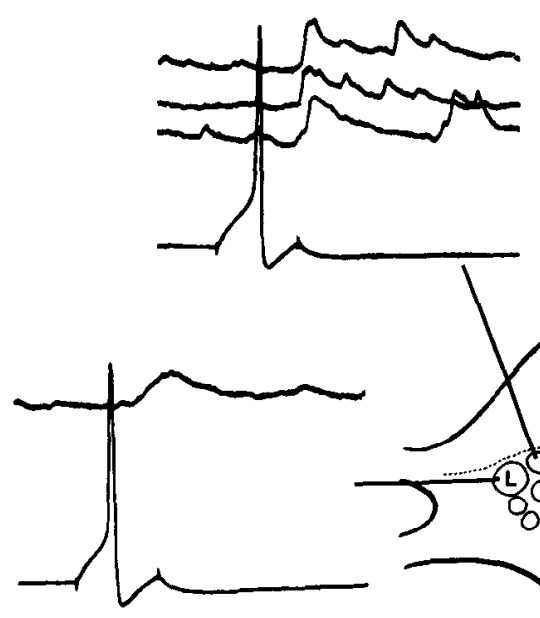

(A)
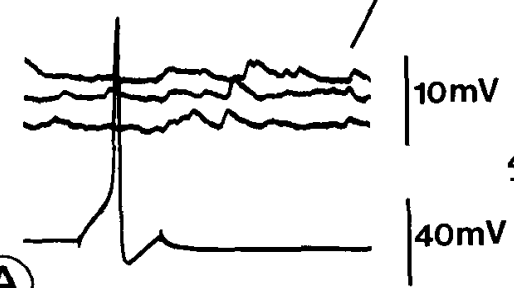

$40 \mathrm{~ms}$
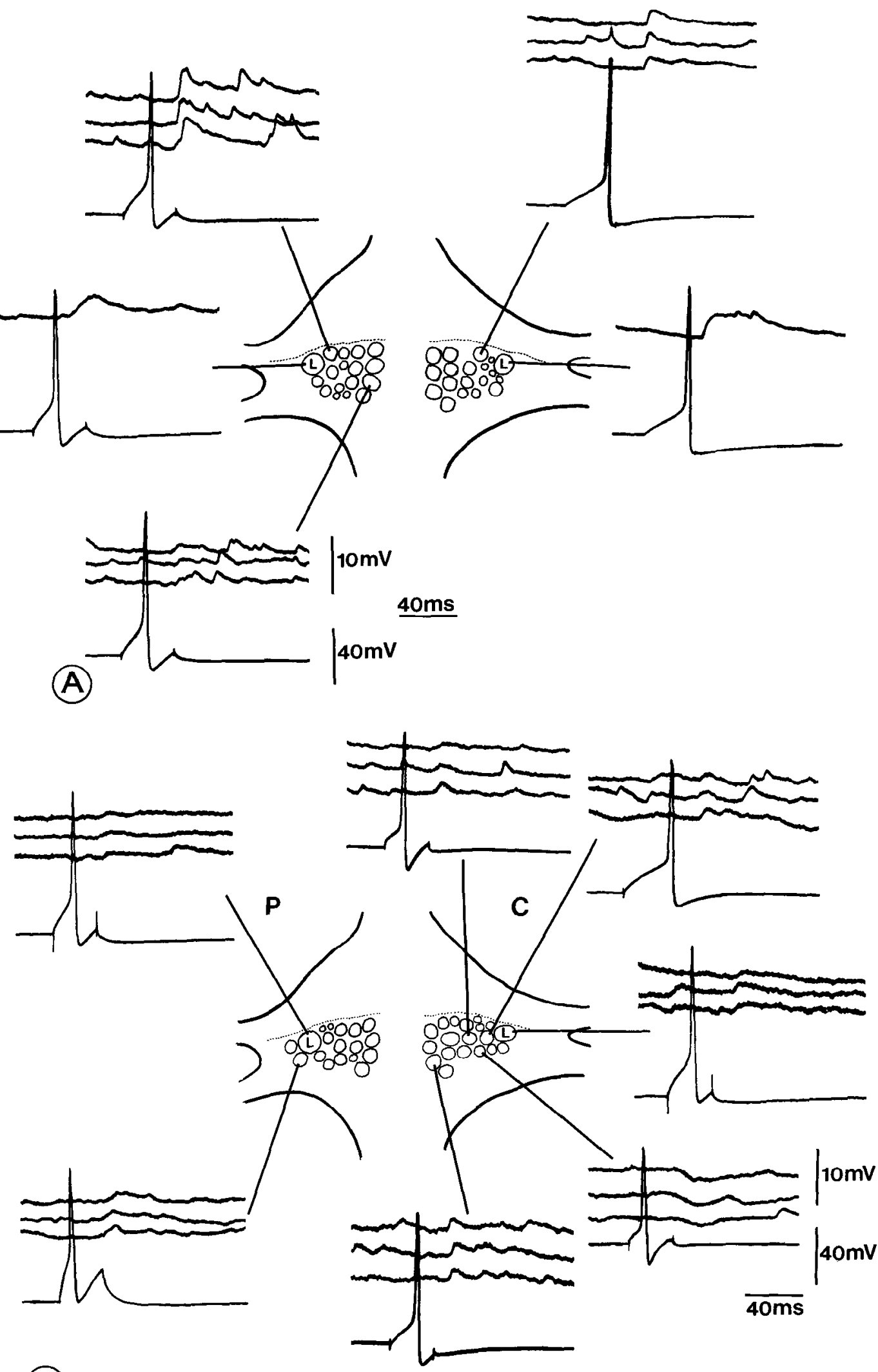

(B)

Figure 3. A, Normal, uninjured preparation shows synaptic potentials (top traces of each record) in cells other than the L motor neuron following action potentials (bottom trace) in pressure cells in the next anterior ganglion. The diagram of the dorsal side of the target ganglion (center) shows positions of the $\mathrm{L}$ cell and other postsynaptic cells. $B$, Regenerated preparation shows synaptic potentials in the $L$ cell, and in other cells as well, evoked by impulses in a regenerated axon of a $P$ cell on the control side $(C)$ and by another on the protease-injected side $(P), 10$ weeks after the lesion was made. 
time after injury: $9 \%$ ( 5 of 57 axons tested) for prepara tions studied 2 to 4 weeks after injury, $12 \%$ (16 of 131) at 5 to 8 weeks, $20 \%$ (27 of 132) at 9 to 12 weeks, and $23 \%$ ( 7 of 31 ) at 13 to 20 weeks. Undoubtedly some of the axons that had not regenerated at early times would have later regenerated successfully. The morphological results were consistent with this. HRP staining revealed that, in most cases, sensory cells that had not regenerated a connection with the target $L$ cell had not yet grown to the next ganglion.

In some of the experiments reported above, sensory axons were severed near their targets, at least threefourths of the way along the connectives toward the next posterior ganglion, while in others axons were severed far from their targets, about one-fourth of the way along the connectives. The overall frequency of successful regeneration in the former group ( $22 \%$, or 42 of 188 axons tested) was significantly greater than in the latter $(8.5 \%$, or 13 of 153 axons tested). This difference might be due in part to the greater time required for axons to grow the greater distance. It could also arise from other factors, such as a greater chance that axons that must grow farther might go astray.

There was some indication that control axons might grow more quickly toward their targets than desheathed axons. In over $50 \%$ of the preparations (24 of 45 ) for which the growth of regenerating axons could be determined reliably in whole mount, the control axon had grown farther than the desheathed axon toward the next ganglion. In a third of the cases, both axons had extended about the same distance, and in the remainder, the desheathed axon had grown farther.

Sprouting by glial-desheathed regenerating axons. In almost all preparations, axons on both control and protease-injected sides sprouted at the site of injury and extended sprouts across the lesion. However, most axons whose ensheathing glial cell was killed also sprouted extensively in the region proximal to the crush, while such sprouting by controls was neither so frequent nor so extensive (Fig. $4 A$ ). Some of the sprouts in the proximal region originated at the crush and grew backward toward the cell body while others emerged from the proximal axon stump along its length.

Desheathed axons that had synapsed with the L motor neuron retained their extensive sprouts within the connective, even in the cases of the three desheathed axons that showed otherwise normal morphology and were considered candidates for axon fusion (Fig. 4C). This implies that sprouts of desheathed axons did not retract after successful regeneration and is consistent with the observation that sprouts of uninjured, desheathed axons remained for up to 10 months (see above). Axons on control sides that had synapsed with the $\mathrm{L}$ motor neuron fell into two morphological categories. Those that looked like normal, mature axons and were considered candidates for axon fusion showed little or no sprouting (Fig. $4 C$ ), whereas those that had followed abnormal pathways or had incomplete ramifications in the target ganglion sprouted to about the same extent as desheathed regenerates (Fig. $4 B$ ).

Not only was the number of sprouts generally greater on the protease-injected sides than on control sides, but their distribution was more widespread. In connectives viewed in cross-section both proximally and distally to the lesion, axon sprouts on protease-injected sides were generally scattered in two or three and sometimes all four quadrants of the connective (Fig. 5). Sprouts of control axons were clustered in the single ventrolateral quadrant in which mechanosensory axons are normally found (C. Kent and K. Muller, unpublished observations). As has been noted for leech nerve cord preparations maintained in culture, $\mathrm{N}$ axons generally sprouted more than $\mathrm{P}$ axons.

Survival of distal sensory axon stumps in the absence of glia. Physiological experiments have indicated that the distal stumps of leech mechanosensory axons survive for months in the peripheral nervous system (Van Essen and Jansen, 1977), and morphological experiments have shown them to survive for at least a month in the CNS (E. J. Elliott, unpublished observations). For technical reasons, in vivo experiments designed to test whether eliminating the glial sheath affected the survival of distal sensory stumps were inconclusive. Similar experiments performed in culture indicated that distal stumps of scnsory axons can survive for up to 3 weeks after their ensheathing glial cell has been killed, but such survival may be less frequent than for normally glial-ensheathed axons.

In these experiments, one connective glial cell was killed in the animal. A week later, a chain of ganglia including the glial-desheathed connective was removed and placed in culture, and one $\mathrm{P}$ or $\mathrm{N}$ cell on each side of the ganglion anterior and adjacent to the glial-desheathed connective was injected with HRP. Two days later, the glial-desheathed connective and its adjacent control connective were crushed, thus severing the axon now filled with HRP. Survival of the distal axon stumps of the HRP-injected sensory cells was monitored morphologically by fixing and staining the preparations at 1-, 2-, and 3-week intervals after injury.

At 1 week, HRP-stained distal stumps remained both in desheathed and in control connectives in all three preparations examined, but in one case the desheathed distal stump was more faintly stained and blebbed, with interruptions along the axon, suggesting the beginning of deterioration. At 2 weeks, the desheathed distal stump of one preparation remained intact; in two others, the desheathed distal stumps were present but not normal; i.e., one was blebbed and the other showed extensive sprouting; in a fourth preparation, no distal stump was detectable in the glial-desheathed connective. At 3 weeks, one preparation contained a healthy desheathed distal stump while a second showed no detectable HRP-stained stump in the desheathed connective. In all of the above preparations, the distal stumps in the control connectives survived and retained a normal, evenly stained appearance. These results are summarized in Table II. What we can safely conclude is that distal axon stumps could survive at least 3 weeks in tissue culture medium, even when the ensheathing glial cell had been killed. Under the experimental conditions, however, the fraction of axons that survived was reduced. 

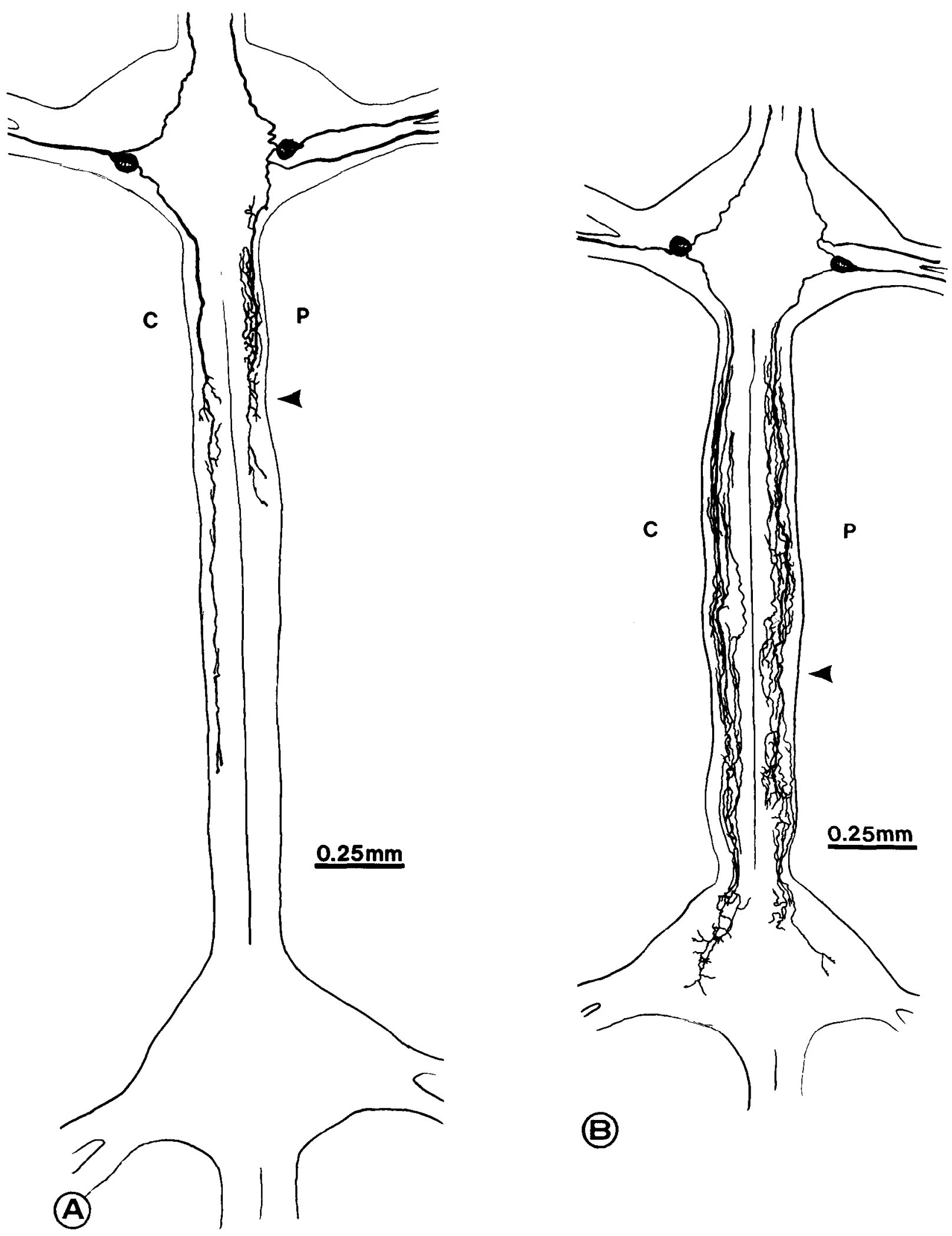

(B)

Figure 4. Camera lucida drawings of HRP-filled regenerating sensory cells. The ensheathing glial cell of one sensory cell axon in each pair was killed by protease injection $(P)$; the other sensory axon served as a control $(C)$. Axons were severed at the arrow. $A$, Two weeks after lesion, a desheathed $\mathrm{P}$ sensory cell axon has sprouted extensively proximal to the site of injury, while a $\mathrm{P}$ cell axon on the control side has extended more sprouts distal to the lesion. $B$, Ten weeks after lesion both a desheathed and a control sensory cell axon have sprouted extensively and grown along unusual pathways in the connectives and into the target ganglion. Physiological recording showed that both axons had formed synapses with the $L$ motor neuron and with other cells 

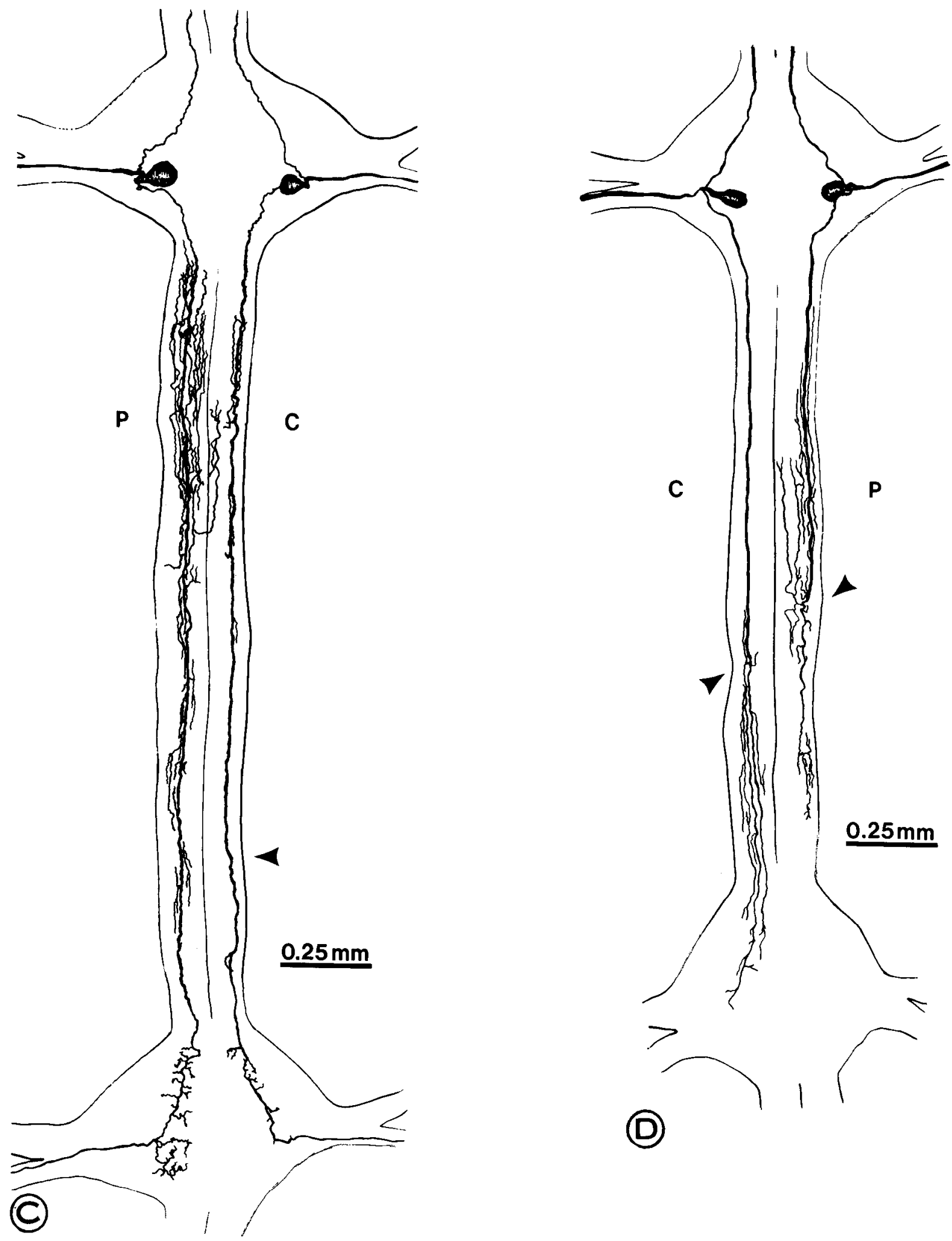

(records shown in Fig. $3 B$ ). C, Four months after lesion, both a desheathed and a control sensory cell axon have regenerated along normal pathways in the connective and thus are considered candidates for fusion with their distal stump. Physiological experiments showed that both axons were synaptically connected to their proper target cells, L motor neurons. Sprouts of the desheathed axon have not retracted even at this late time. $D$, Physiological experiments showed both of these cells to be synaptically connected to L motor neurons in the next ganglion. HRP-filled processes of the desheathed axon, however, do not extend all the way to the target ganglion. In each of the above drawings, many processes in the anterior ganglion have been omitted. 


\section{Discussion}

The above experiments indicate that, after destruction of their ensheathing glial cell, mechanosensory axons continued to function normally, although in some cases they grew collateral sprouts, i.e., sprouts from the length of the axon. Such sprouting might be triggered by mechanisms similar to those suggested to play a role in injuryinduced sprouting of intact nerves in other systems (Diamond, 1979). In particular, the sensory axons may have sprouted in response to glial degeneration products and general inflammation, or in response to macrophage invasion (Brown et al., 1981; Cotman et al., 1981). This would then be the first example of degeneration products inducing collateral sprouts rather than terminal sprouts solely at the synaptic region (Cotman et al., 1981). Al-

TABLE I

Distribution of successfully regenerated sensory axons according to pathway of growth in the connectives and target ganglion

The normal pathway is in the ventrolateral quadrant of the connectives (see the text).

\begin{tabular}{lcc}
\hline & Control & $\begin{array}{c}\text { Glial } \\
\text { Cell Killed }\end{array}$ \\
\hline Total axons tested & 173 & 162 \\
Number of axons regenerated to L cell & 31 & 24 \\
Pathway normal & 8 & 3 \\
Pathway abnormal & 6 & 6 \\
Pathway not determined & 17 & 15 \\
\hline
\end{tabular}

ternatively, removal of the glial cell may have removed a glial inhibitory action, either physical or trophic, on axons that might otherwise have sprouted at many points along their length. The degree to which glial killing induced sprouting varied for different types of axons and correlates with the degree to which those axons sprout in response to other stimuli, such as nerve injury. Thus, $\mathrm{N}$ cell axons, which sprout more than $\mathrm{P}$ cell axons when severed, generally sprouted more than $\mathrm{P}$ axons in response to glial killing. Similarly, axons of the S cell, a leech neuron that sprouts much less extensively after injury than do sensory axons, do not sprout detectably in response to elimination of their glial sheath (E. J. Elliott and K. J. Muller, manuscript in preparation).

After being severed, glial-desheathed axons regenerated and became reconnected to their correct target cells about as frequently and selectively as in normal regeneration. Removal of the glial cell often had a significant effect on the growth of regenerating axons, causing more extensive sprouting, more sprouting proximal to the lesion, and perhaps slowing growth. Regeneration in the absence of the glial cell may have proceeded along abnormal pathways, as judged by location within the connective, more frequently than usual, and perhaps involved polysynaptic pathways. The effect of glial loss on the pathway of regeneration is difficult to assess, however, due to the possibility of axon fusion as a mechanism by which axons could have regenerated with normal morphology.

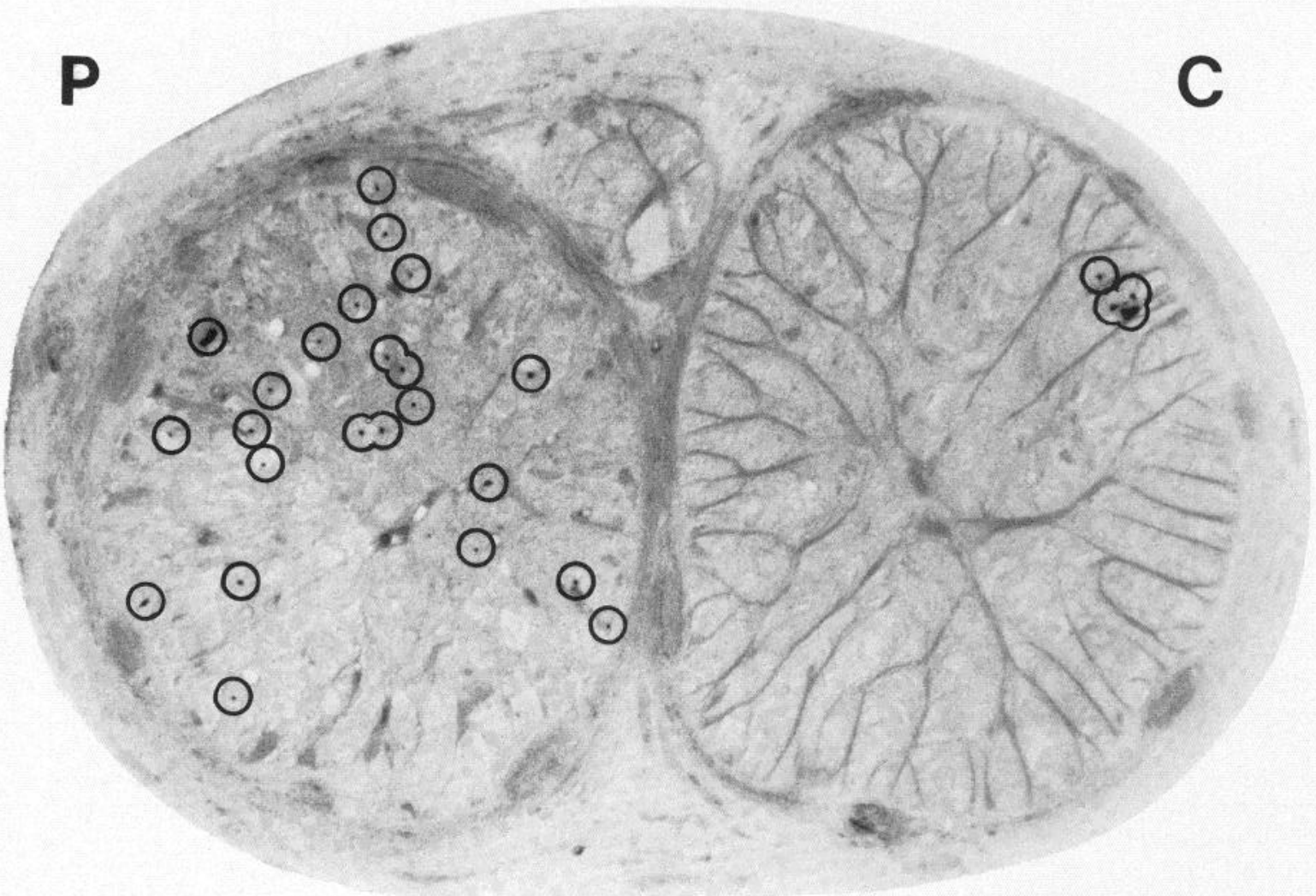

$50 \mu \mathrm{m}$

Figure 5. A cross-section through the connectives shows the distribution of sprouts of a regenerating $\mathrm{P}$ sensory axon in a connective in which the glial cell was killed by protease injection $(P)$ and of a regenerating axon in a control connective $(C)$. The glial cell was killed 1 week before the connectives were crushed. P cell bodies were injected with HRP 6 weeks later. 
TABLE II

Fraction of sensory axon distal stumps that retained normal morphology (i.e., did not sprout, change in diameter, or disappear) in culture in the presence of, and in the absence of, the ensheathing glial cell

\begin{tabular}{ccc}
\hline & Control & Glial Cell Killed \\
\hline $1 \mathrm{wk}$ & $3 / 3$ & $2 / 3$ \\
$2 \mathrm{wk}$ & $4 / 4$ & $1 / 4$ \\
$3 \mathrm{wk}$ & $2 / 2$ & $1 / 2$ \\
\hline
\end{tabular}

Distal stumps of mechanosensory axons survived in the absence of ensheathing glia for as long as 3 weeks in culture. Whether such desheathed distal stumps can survive as long as they can when normally ensheathed, i.e., several months (Van Essen and Jansen, 1977), has not yet been determined. There was some indication that, within the 3 -week time period, desheathed sensory axons might not survive as well as glial-ensheathed stumps. However, desheathed distal stumps of the $\mathrm{S}$ cell axon can survive as long as normally ensheathed $S$ axon stumps (E. J. Elliott and K. J. Muller, manuscript in preparation). Glia have been proposed to help support distal axon stumps in other systems, perhaps by transfer of metabolites or macromolecules (Meyer and Bittner, 1978a, b). However, unlike some other invertebrate systems (Gainer et al., 1977; Lasek et al., 1977; Goldstein et al., 1982), in the leech there is no evidence for transfer of large molecules, such as HRP or protease, between glia and neurons (Globus et al., 1973; Elliott and Muller, 1981). Moreover, again in contrast to reports on other invertebrate systems (Peracchia, 1981; Viancour et al., 1981 ), in the leech there is no evidence for electrical coupling or Lucifer Yellow dye coupling between glia and neurons (Kuffler and Potter, 1964; Elliott and Muller, 1981; E. Elliott and K. Muller, unpublished results). The possibility remains that distal axon stumps receive some trophic support from the microglia that increase in number at an injury site (Morgese et al., 1983) and after glial killing.

The final distance over which the regenerating sensory axons had to grow to reach their proper target cells was, in these experiments, still ensheathed by the packet glia and neuropil glia of the ganglion. Thus, these glia were available to guide the final growth of the sensory axons. In studies on regeneration of the $\mathrm{S}$ cell in the leech CNS, we have found that electrical synapses form with normal frequency and accuracy in a glial desheathed region ( $\mathrm{E}$. J. Elliott and K. J. Muller, manuscript in preparation). Other evidence that the glial cell is not required for nerve cell recognition comes from in vitro experiments in which individual $\mathrm{P}$ sensory neurons, dissected from the ganglion and cultured free of glial ensheathment, formed connections selectively with isolated $\mathrm{L}$ motor neurons placed next to them in a dish (Fuchs et al., 1981).

How regenerating axons are directed to the vicinity of their targets remains an open question. Since some regenerating sensory axons followed markedly aberrant courses within the connectives and still succeeded in reestablishing synaptic connections with the correct target cell, it seems that any requirement for guidance of regenerating axons must not be stringent. However, loss of the glial cell does induce increased sprouting proximally as well as distally to the lesion, and it is conceivable that aberrantly positioned axons nonetheless follow usual neighbors into the next ganglion. There is some evidence that points to extracellular channels formed by glial cells as guides in the development and regeneration of axons (Singer et al., 1979; Silver and Robb, 1979; Silver and Sidman, 1980; Silver et al., 1982). In our experiments, electron microscopy often showed channels of extracellular space left by removal of the glial cell. Regenerating axons may have grown preferentially along these channels, whether labeled or not. It is possible that, in this system as in some others, regenerating sensory axons do not require precise pathway guidance but simply tend to grow in the direction in which most other elements are oriented, i.e., longitudinally along the connectives. The nature of those elements, whether glial or axonal or extracellular, might not be critical. Upon arriving in the vicinity of the synaptic target, the regenerating axons might then rely upon neuron-specific growth and recognition factors to direct them to their targets.

\section{References}

Aguayo, A. J., S. David, P. Richardson, and G. M. Bray (1982) Title. In Advances in Cellular Neurobiology, S. Fedoroff and L. Hertz, eds., pp. 215-234, Academic Press, Inc., New York. Baylor, D. A., and J. G. Nicholls (1969) Changes in extracellular potassium concentration produced by neuronal activity in the central nervous system of the leech. J. Physiol. (Lond.) 203: 555-569.

Baylor, D. A., and J. G. Nicholls (1971) Patterns of regeneration between individual nerve cells in the central nervous system of the leech. Nature 232: 268-269.

Bowling, D., J. Nicholls, and I. Parnas (1978) Destruction of a single cell in the central nervous system of the leech as a means of analysing its connexions and functional role. J. Physiol. (Lond.) 282: 169-180.

Brown, M. C., R. L. Holland, and W. G. Hopkins (1981) Motor nerve sprouting. Annu. Rev. Neurosci. 4: 1742.

Carbonetto, S., and K. J. Muller (1977) A regenerating neurone in the leech can form an electrical synapse on its severed axon segment. Nature (Lond.) 267: 450-452.

Cotman, C. W., M. Nieto-Sampedro, and E. W. Harris (1981) Synapse replacement in the nervous system of adult vertebrates. Physiol. Rev. 61: 684-784.

DeRiemer, S. A., E. J. Elliott, E. R. Macagno, and K. J. Muller (1983) Morphological evidence that regenerating axons can fuse with severed axon segments. Brain Res., in press.

Diamond, J. (1979) The regulation of nerve sprouting by extrinsic influences. In The Neurosciences: Fourth Study Program, F. O. Schmitt and F. G. Worden, eds., pp. 937-955, MIT Press, Cambridge, MA.

Elliott, E. J., and K. J. Muller (1981) Long-term survival of glial segments during nerve regeneration in the leech. Brain Res. 218: 99-113.

Elliott, E. J., and K. J. Muller (1982) Synapses between neurons regenerate accurately after destruction of ensheathing glial cells in the leech. Science 215: 1260-1262.

Fernandez, J. H., and M. S. G. Fernandez (1974) Morphological evidence for an experimentally induced synaptic field. Nature (Lond.) 251: 428-430.

Frank, E., J. K. S. Jansen, and E. Rinvik (1975) A multisomatic axon in the central nervous system of the leech. J. Comp. Neurol., 159: 1-14.

Fuchs, P. A., J. G. Nicholls, and D. F. Ready (1981) Membrane properties and selective connexions of identified leech neurones in culture. J. Physiol. (Lond.) 316: 203-223. 
Fuchs, P. A., L. P. Henderson, and J. G. Nicholls (1982) Chemical transmission between individual Retzius and sensory neurones of the leech in culture. J. Physiol. (Lond.) 323: 195-210.

Gainer, H., I. Tasaki, and R. J. Lasek (1977) Evidence for the glia-neuron protein transfer hypothesis from intracellular perfusion studies of squid giant axons. J. Cell Biol. 74: 524530 .

Globus, A., H. D. Lux, and P. Schubert (1973) Transfer of amino acids between neuroglia cells and neurons in the leech ganglion. Exp. Neurol. 40: 104-113.

Goldstein, R. S., K. R. Weiss, and J. H. Schwartz (1982) Intraneuronal injection of horseradish peroxidase labels glial cells associated with the axons of the giant metacerebral neuron of Aplysia. J. Neurosci. 2: 1567-1577.

Hoy, R. R. (1969) Degeneration and regeneration in abdominal flexor motor neurons in the crayfish. Exp. Zool. 172: 219232.

Hoy, R. R., G. D. Bittner, and D. Kennedy (1967) Regeneration in crustacean motoneurons: Evidence for axonal fusion. Science 156: 251-252.

Jansen, J. K. S., and J. G. Nicholls (1972) Regeneration and changes in synaptic connections between individual nerve cells in the central nervous system of the leech. Proc. Natl. Acad. Sci. U. S. A. 69: 636-639.

Jansen, J. K. S., K. J. Muller, and J. G. Nicholls (1974) Persister, modification of synaptic interactions between sensory and motor nerve cells following discrete lesions in the central nervous system of the leech. J. Physiol. (Lond.) 242: 289-305.

Kao, C. C., L. W. Chang, and J. M. B. Bloodworth (1977) Axonal regeneration across transected mammalian spinal cords: An electron microscopic study of delayed microsurgical nerve grafting. Exp. Neurol. 54: 591-615.

Kuffler, S. W., and D. D. Potter (1964) Glia in the leech central nervous system: Physiological properties and neuron-glia relationship. J. Neurophysiol. 27: 290-320.

Lasek, R. J., H. Gainer, and J. L. Barker (1977) Ccll-to-cell transfer of glial proteins to the squid giant axon. The glianeuron protein transfer hypothesis. J. Cell Biol. 74: 501-523.

Luft, J. H. (1971a) Ruthenium red and violet. I. Chemistry, purification, methods of use for electron microscopy and mechanism of action. Anat. Rec. 171: 347-368.

Luft, J. H. (1971b) Ruthenium red and violet. II. Fine structural localization in animal tissues. Anat. Rec. 171: 369-416.

Macagno, E. R., S. A. DeRiemer, and K. J. Muller (1982) Regeneration of effective but aberrantly distributed synapses by sensory neurons in the leech CNS. Soc. Neurosci. Abstr. 8: 868.

Meyer, M. R., and G. D. Bittner (1978a) Histological studies of trophic dependencies in crayfish giant axons. Brain Res. 143: 195-211.

Meyer, M. R., and G. D. Bittner (1978b) Biochemical studies of trophic dependencies in crayfish giant axons. Brain Res. 143: $213-232$.

Morgese, V. J., E. J. Elliott, and K. J. Muller (1983) Microglial movement to sites of nerve lesion in the leech. Brain Res., in press.

Muller, K. J. (1979) Synapses between neurones in the central nervous system of the leech. Biol. Rev. 54: 99-134.

Muller, K. J., and S. Carbonetto (1979) The morphological and physiological properties of a regenerating synapse in the C.N.S. of the leech. J. Comp. Neurol. 185: 485-516.

Muller, K. J., and U. J. McMahan (1976) The shapes of sensory and motor neurones and the distribution of their synapses in the ganglia of the leech: A study using intracellular injection of horseradish peroxidase. Proc. R. Soc. Lond. Biol. 194: 481499.
Murray, M. (1976) Regeneration of retinal axons into the goldfish optic tectum. J. Comp. Neurol. 168: 175-196.

Nicholls, J. G., and D. Purves (1970) Monosynaptic chemical and electrical connexions between sensory and motor cells in the central nervous system of the leech. J. Physiol. (Lond.) 209: 647-667.

Ort, C. A., W. B. Kristan, Jr., and G. S. Stent (1974) Neuronal control of swimming in the medicinal leech. II. Identification and connections of motor neurons. J. Comp. Physiol. 94: 121-154.

Parnas, I., and D. Bowling (1977) Killing of single neurones by intracellular injection of proteolytic enzymes. Nature (Lond.) $270 \cdot 626-628$.

Peracchia, C. (1981) Direct communication between axons and sheath glial cells in crayfish. Nature (Lond.) 290: 597-598.

Ramon y Cajal, S. (1928) Degeneration and Regeneration in the Nervous System, Hafner, New York.

Ready, D. F., and J. Nicholls (1979) Identified neurones isolated from leech CNS make selective connections in culture. $\mathrm{Na}$ ture (Lond.) 281: 67-69.

Reier, P. J., and H. de F. Webster (1974) Regeneration and remyelination of Xenopus tadpole optic nerve fibres following transection or crush. J. Neurocytol. 3: 591-618.

Sanes, J. R., L. M. Marshall, and U. J. McMahan (1978) Reinnervation of muscle fiber basal lamina after removal of myofibers. J. Cell Biol. 78: 176-198.

Scott, S. A., and K. J. Muller (1980) Synapse regeneration and signals for directed axonal growth in the central nervous system of the leech. Dev. Biol. 80: 345-363.

Silver, J., and R. M. Robb (1979) Studies on the development of the eye cup and optic nerve in normal mice and mutants with congenital optic nerve aplasia. Dev. Biol. 68: 175-190.

Silver, J., and R. L. Sidman (1980) A mechanism for the guidance and topographic patterning of retinal ganglion cell axons. J. Comp. Neurol. 189: 101-111.

Silver, J., S. E. Lorenz, D. Wahlsten, and J. Coughlin (1982) Axonal guidance during development of the great cerebral commissures: Descriptive and experimental studies, in vivo, on the role of preformed glial pathways. J. Comp. Neurol. 210: 10-29.

Singer, M., R. H. Nordlander, and M. Egar (1979) Axonal guidance during embryogenesis and regeneration in the spinal cord of the newt: The blueprint hypothesis of neuronal pathway patterning. J. Comp. Neurol. 185: 1-22.

Stensaas, L. J., P. R. Burgess, and K. W. Horch (1979) Regenerating dorsal root axons are blocked by spinal cord astrocytes. Soc. Neurosci. Abstr. 5: 684 .

Stewart, W. W. (1981) Lucifer dyes-highly fluorescent dyes for biological tracing. Nature (Lond.) 292: 17-21.

Stuart, A. E. (1970) Physiological and morphological properties of motoneurones in the central nervous system of the leech. J. Physiol. (Lond.) 209: 627-646.

Turner, J. E., and M. Singer (1974) The ultrastructure of regeneration in the severed newt optic nerve. J. Exp. Zool. 190: 249-268.

Van Essen, D. C., and J. K. S. Jansen 1977) The specificity of reinnervation by identified sensory and motor neurons in the leech. J. Comp. Neurol. 171: 433-454.

Viancour, T. A., G. D. Bittner, and M. L. Ballinger (1981) Selective transfer of Lucifer Yellow $\mathrm{CH}$ from axoplasm to adaxonal glia. Nature, 293: 65-67.

Wallace, B. G., M. N. Adal, and J. G. Nicholls (1977) Regeneration of synaptic connections by sensory neurons in leech ganglia maintained in culture. Proc. R. Soc. Lond. Biol. 199: $567-585$.

Weinberg, E. L., and C. S. Raine (1980) Reinnervation of peripheral nerve segments implanted into the rat central nervous system. Brain Res. 198: 1-11. 